Published as: Kate Macdonald and Terry Macdonald, "Democracy in a Pluralist Global Order: Corporate Power and Stakeholder Representation", Ethics and International Affairs, 24.1 (2010), pp.19-43

\title{
Democracy in a Pluralist Global Order: Corporate Power and Stakeholder
}

\section{Representation}

Kate Macdonald and Terry Macdonald

The primary task undertaken by the liberal-democratic project throughout its modern history has been that of legitimately constituting and controlling the public powers wielded by sovereign states. As such, the principal institutions of modern representative democratic systems — constitutional structures and electoral processes-have consistently been developed with state power as the target for democratic control. However, contemporary democrats concerned with the project of building democratic institutions on a global scale now confront a new and important set of questions about how far we should expect any global democratic mechanisms to resemble the familiar democratic institutions employed within states.

Whereas representative democratic mechanisms have generally been built around preexisting institutional structures of sovereign states (through processes of state democratization), the global political domain infamously lacks any firmly constitutionalized or sovereign structures that could constitute an analogous institutional backbone within a democratic global order; instead, global public power can best be characterized as "pluralist" in structure. ${ }^{1}$ A number of prominent commentators have recently argued that this structural difference between state-based and global forms of political power has significant implications for the prospects of global democracy. Most 
notably, Thomas Nagel has argued that we should not expect a project of global democratization to succeed in the absence of a global framework of sovereign power, since institutions of democratic control need preexisting sovereign structures to "go to work on.” If global democratization is to succeed at all, Nagel argues, it must proceed along a trajectory beginning with the construction of sovereign institutions and culminating in the establishment of representative institutions to control them. ${ }^{3}$

The broad goal of this paper is to challenge this influential view of the preconditions for global democratization and to explore some possible institutional means for establishing representative democratic institutions at the global level within the present pluralist structure of global power. In so doing, we will consider two questions: (1) How might it be possible to build representative democratic institutions in global politics in the absence of sovereign global structures of public power? and (2) How will representative democratic institutions at the global level need to differ from those within sovereign states if they are to be capable of overseeing and controlling the plural institutional forms of global public power?

In order to gain firmer traction on these questions, we focus our analysis on the prospects for democratic control of corporate power, as constituted and exercised in one particular institutional context: sectoral supply chain systems of production and trade. For illustrative purposes, our analysis draws extensively on case studies of the global garment and coffee industries. We draw in particular on evidence collected during ten months of multisited field research, beginning in coffee- and garment-producing communities in Nicaragua, and following transnational supply chains through to consumption sites in the United States and Europe. ${ }^{4}$ Because global production systems in these industries connect 
some of the world's poorest workers in the global South with affluent and powerful consumer markets and corporate entities in the global North, the exercise of corporate power in these cases generally has significant implications for the basic livelihoods and freedoms of the marginalized workers and producers involved. For these reasons, analysis of prospective institutional avenues for democratizing this corporate power is instructive in thinking through the broader institutional challenges for democrats posed by the current global structure. ${ }^{5}$

The paper argues that democratization can indeed proceed at a global level in the absence of sovereign structures of public power. We also maintain, however, that global democratization cannot be straightforwardly achieved simply by replicating familiar representative democratic institutions (based on constitutional separations of powers and electoral control) on a global scale, since the lack of sovereign structures does pose serious obstacles for democrats. As such, this paper aims both to clarify the nature of the distinct institutional challenges posed to democrats by the pluralist structure of global public power, and to explore some potential institutional strategies for overcoming these obstacles, in relation to the forms of corporate power on which we focus our analysis.

Our analysis is developed in three sections. The first two sections aim to clarify the particular institutional challenges posed to democrats by the pluralist structure of global public power. These challenges are articulated first in theoretical terms, and then with more concrete reference to the features of corporate public power wielded within supply chain systems of production and trade. The final section sets out some plausible institutional strategies for democratizing corporate public power within the pluralist global structure, and highlights important structural limitations inherent in these strategies. 


\section{Structures of “Public Power” and Their Democratic Implications}

\section{What Is "Public" Power?}

To help frame a theoretical understanding of the democratic challenges posed by the existing global political order, we begin here by outlining more explicitly what we mean by the concept of "public power." In simple terms, the concept refers here to those forms of power that are the legitimate subject of democratic control; that is, we can characterize as "public" all social power that needs to be institutionally harnessed to serve public democratic values, and institutionally restrained to protect these values from the potential abuse of power.

The manner in which this abstract conception of public power translates into concrete claims about which instances of social power should count as "public" principally depends on what we take to be the underlying public democratic values that provide the principled basis for the democratic project. For liberal democrats (such as we identify ourselves here), these are the core values of individual autonomy and equality. On a liberal-democratic account, we can thus specify that social power should qualify as "public" when it prospectively affects in some problematic way the equal autonomous entitlements of individuals such that there is a normative imperative for its democratic control. $^{6}$

There is of course considerable scope for disagreement among democrats about precisely what range of political impacts on the material well-being and life choices of populations would undermine protection of individuals' equal democratic entitlements to 
autonomy. For the purposes of the following discussion, we do not attempt to elaborate any more detailed account of which particular resources, institutional protections, and opportunities individuals must attain in order to satisfy this broad liberal-democratic ideal. These questions remain the subject of ongoing discussion in the context of wider theoretical and political debates about democratic ideals of rights, citizenship, and social justice. As such, a fully specified criterion for delineating public power must be worked out in each political context in which democratic control is to be established, to reflect the varying degrees of responsibility for others' autonomy that can gain broad political consensus (and thus deliver legitimacy) in each. ${ }^{7}$ A broad normative criterion of the kind we stipulate here can, however, set the conceptual and normative parameters for this task, and thus helpfully orient the political project of delineating and institutionalizing a clear framework of democratic public power.

In addition to this foundational normative criterion of publicness, we can identify certain structural institutional properties of publicness. In order for effective representative democratic control over public power to be exercised in practice, democratic institutions must be capable of opening the exercise of public power to institutionalized public focus, scrutiny, and political critique. This requires that agencies of pubic power possess certain structural institutional characteristics.

First, it is important that agencies of public power constituted within the overarching political structure have a significant degree of institutional stability. Social actors can sometimes generate significant and problematic political impacts through haphazard or one-off decisions or actions, but it will not be feasible or productive to subject these instances of power to democratic control if the agents in question do not 
engage in political actions in a reasonably predictable way. One key reason for this is that it takes time to establish representative democratic institutions effectively. Moreover, such institutions tend to exercise more effective control over those political decision-makers wielding power over a longer time frame.

Another reason it is important that those wielding power do so in a stable and institutionalized fashion is that stability of political roles will generally make it much easier for others to trace and identify the political impacts generated by particular agents' actions, which is a necessary prerequisite for holding political agents responsible. To put this in more general terms, institutional stability of political roles can contribute to a second institutional characteristic essential for responsible political agency: transparency of political roles within the institutional structure-that is, the availability and accessibility of information about the kinds of political actions undertaken by particular actors, and the kinds of political impacts these actions generate. Transparency of political roles can further be promoted by the formal codification of the political roles and responsibilities of particular actors, and by the establishment of institutions that provide external social recognition of organizational roles and responsibilities, such as watchdog institutions of various kinds.

\section{“Sovereign” versus "Pluralist” Structures of Public Power}

On standard state-based models of liberal democracy, all power that qualifies as "public" in the above sense is assumed to be concentrated within the "sovereign" institutional structures constitutive of statehood. Within a sovereign structure, all public power within a given territory is centralized or constitutionalized in a unified institutional apparatus, such 
that all specific public political roles and responsibilities are allocated to different decisionmaking levels in accordance with some unified ordering principles.

In line with this standard model of democratic public power as sovereign in structure, the process of democratization is commonly conceptualized as entailing two distinct institutional phases. The first of these involves the creation of sovereign institutions - to ensure that the power of the plural actors within "civil society" is controlled and limited to ensure the protection of a designated democratic "common good" or "public interest." Second, the public power of the state is brought under collective democratic control by all the individuals within civil society that are subject to its regulatory restraints. In sum, the standard model of democratization suggests that public power is ideally concentrated within a sovereign framework of public power, prior to (hypothetically if not temporally) the establishment of democratic procedures for political control.

For present purposes, the significance of this two-phase model of democratization is that it highlights how the normative quality of "publicness" identified above-that is, the quality of affecting populations in ways that implicate fundamental public values and thus require special democratic controls-is logically quite separable from the structural institutional characteristics of sovereign power as just described. It is a matter of historical and political contingency whether the powers in possession of these special normative impacts within a given social context will also be centralized or constitutionalized in institutional structure.

We contend here that whereas much of the public power wielded internal to democratic states is concentrated in sovereign institutional structures, the same cannot be 
said for the public power wielded across and beyond the boundaries of sovereign states, as a product of globalization. The existing system of sovereign states and international law perform public regulatory functions to a limited degree. However, such nonstate actors as transnational corporations (TNCs) and nongovernmental organizations (NGOs), alongside a plurality of states and intergovernmental organizations, wield many of the forms of "public” decision-making power (in fields of lawmaking, economic development, public service provision, and so on) that democrats have traditionally sought to subject to public regulatory control. ${ }^{8}$

We propose that these multiple public political agencies within the contemporary global system can best be characterized as "pluralist” (rather than "sovereign”) in structure. Although public power within a sovereign structure is generally internally divided into multiple agencies (through complex institutional separation, or functional differentiation, of public power through constitutions and bureaucracies), the pluralist global structure differs in several key respects.

First, the dispersion of public power among myriad state and nonstate actors in global politics generates a much more organizationally complex network of public political agencies than that embodied in the separation of powers within a state. Moreover, these multiple state and nonstate actors are radically decentralized —in the sense that they are not organizationally connected within any overarching constitutional structure allocating complementary roles and responsibilities in relation to a shared democratic public, as are the multiple public agencies within the state. Relatedly, these multiple state and nonstate actors are differentiated not only functionally (as are the various public agencies within the state) but also jurisdictionally. By this we mean that public political agents can affect 
distinct (though often overlapping) public stakeholder constituencies, rather than all affecting the same unified democratic "public" of the kind constituted through the centralized institutions of a state. For example, the public stakeholder jurisdiction of a corporation (which we suggest should be accountable primarily to affected workers within its production chains) can be quite different from the public jurisdiction of a government (which must be accountable primarily to the residents subject to its laws). ${ }^{9}$

\section{Democratic Challenges Posed by a Pluralist Structure of Public Power}

With this understanding of the distinct features of a pluralist structure of public power in mind, we are in a position to tackle the central question: What are the special institutional challenges to a project of democratic institution-building posed by a pluralist structure of public power? Here we highlight two key institutional challenges.

First, certain normative and practical difficulties arise for institutions of electoral representation in the context of a pluralist structure of public power. Within sovereign states, elections have traditionally served as the principal mechanisms for instituting representative democratic control of public power. Typically not all public agents are directly elected, since to conduct elections for every public office would be enormously costly (in both time and resources) and therefore impractical. Instead, generally only a small subset of public officials is directly elected-parliamentarians in some systems, executives in others, and so on. The representative legitimacy of the remaining categories of public officials is then achieved through processes of delegation, whereby democratic authority is transferred from elected to unelected officials. Since elected public agents and their various public delegates all share the same public constituency within a sovereign 
structure- the entire citizenry of the state-unelected public agents can thus be subjected to representative democratic control indirectly, through the delegatory chain of control.

In contrast, within a pluralist (nonsovereign) structure of public power such as we have in contemporary global politics, the capacity to achieve representative legitimacy for the myriad agencies of public power via such delegatory chains is significantly diminished. The various state and corporate public political actors operating in the pluralist global domain can have quite different constituencies, and moreover tend to affect different groups of stakeholders in very different ways and to very different degrees (as we discuss in more empirical detail below). As such, these multiple political agencies cannot achieve representative legitimacy via delegation of authority among them in the same way that the various public agencies within a state structure are able to do. For this reason, each of these global political agents could only be subjected to legitimate representative democratic control by its own stakeholder community, through some direct accountability procedure.

This does not rule out in principle the possibility of employing electoral mechanisms to meet the multiple overlapping demands for representative democratic control that arise between plural public political agents and their overlapping stakeholder constituencies within global politics, but there would be serious problems associated with doing so. First, there would be certain normative problems with employing electoral representation in relation to pluralist structures of public power, since the aggregative social choice mechanism embodied in elections would struggle to take fair democratic account of the sometimes widely varied intensities of impact and interest at stake in the decisions of plural agents of public power. ${ }^{10}$ Moreover, the complexity of the electoral framework that would be required to connect each distinct public decision-maker to its 
own stakeholder community would create serious impediments at a practical level. Not only would an enormously complex, costly, and confusing network of electoral processes be required to establish separate representative controls for each of the organizationally disparate public political agents, but also many of the elaborate logistical demands of free and fair elections (such as protections against electoral fraud) would be impracticable to establish within territorially and socially dispersed stakeholder constituencies.

The second major challenge confronting attempts to democratize a pluralist structure of public power is that nonsovereign forms of public power (such as corporate power) sometimes lack the sorts of institutional properties of publicness that are practical prerequisites for effective democratic control. As discussed above, the most important of these properties are institutional stability and transparent public role delineation.

One of the democratic advantages of a sovereign structure of public power is that it embodies high degrees of both institutional stability and transparent public role delineation. While it is in principle possible for nonsovereign forms of public power to embody some of these institutional properties of publicness, sovereign structures of public power are at an advantage over pluralist structures in this area. This is because the constitutionalized structure of sovereign power can help to stabilize and codify political roles and responsibilities, and thus generate the kind of recognition and transparency of political roles and impacts that we have explained is important to facilitate effective democratic control. The more stable and formally codified a structure of power, and the more entrenched the broader institutions of social recognition surrounding it, the easier it will be to attribute responsibility for the political impacts generated by the agencies 
constituted through it; correspondingly, the easier it will be to identify these political agencies as "public," and subject them to democratic control.

Insofar as the constitutional structures of the sovereign state seek explicitly to achieve the task of increasing the stability, clarity, and recognition of roles and responsibilities within the overarching territorial political structure, a sovereign structure of public power is likely in general to embody the institutional properties of publicness to a higher degree than a non-constitutionalized pluralist structure of public power. The relative institutional weakness of pluralist structures in this respect constitutes the second key challenge posed to the project of global democratization by the existing pluralist structure of public power.

\section{Economic Globalization and the "Pluralization" of Public Power}

Thus far we have articulated the challenges posed to democrats by the pluralist structure of global public power in general theoretical terms. In this section our goal is to illustrate with some greater degree of empirical detail the kinds of concrete democratic challenges entailed by this in practice, with a specific focus on the problem of subjecting transnational corporate power to democratic control.

\section{The Organization of Corporate and Market Power}

In both of the industries examined here, corporate power is currently structured within institutions commonly described as "global supply chains." This term refers to the whole spatially dispersed organizational system of functionally interconnected inputs and 
processes through which production and distribution are coordinated within given industries. Supply chain institutions in the garment and coffee industries take a wide variety of organizational forms; typically they involve institutionalized coordination among some combination of firms (or other vertically integrated production units), markets, and relational networks of diverse kinds. Within the buyer-driven supply chains that dominate both industries, decision-making is coordinated and controlled primarily by large retailers and branded merchandizers based in industrialized countries; these are "brands" and retailers in the garment sector, and roasting companies in coffee. The control of such corporate buyers over strategic marketing and design activities enables them to wield extensive power over decision-making throughout the global chain. ${ }^{11}$

Power organized within these supply chains is dispersed among a broad range of public decision-makers of diverse kinds, in the absence of clearly defined allocations of public roles and responsibilities. In the garment industry, decision-making power is distributed between the lead retailers and/or brands at the top of the chain and a range of other corporate actors that generally includes traders, importers, and factory owners and managers. In the coffee industry, power is distributed between the roasters, who tend to adopt the lead role within chains, and often long chains of intermediaries, including importers, exporters, processors, intermediate traders, and (in the case of large plantations) farm owners and managers. While our focus is on the power exercised by corporate actors within global supply chains, a range of state agencies and institutions within both producing and importing countries also wield important forms of power over workers and producers - directly, and via their contribution to the shaping of wider processes of rural development in producing countries. 


\section{The Normative Significance of Corporate Power}

To establish that these forms of corporate power are public in the normative sense relevant to a project of democratization, the first thing we need to demonstrate is that the decisions made within these supply chain institutions affect other actors (stakeholders) in ways that threaten the equal autonomous entitlements of these populations, thus generating a normative imperative for democratic control. The extent of the power wielded by brands and retailers, and the range of well-being outcomes for workers and producers that they control, varies significantly between and within the garment and coffee industries.

In the garment industry, key variables relating to material welfare-in particular, both wages and health and safety-are of central importance. A key complaint of workers in Nicaragua is that their wages fail to cover the basic cost of living - a claim that is unambiguously supported by official estimates of the basic basket of goods. With regard to health and safety, common problems described by workers relate not only to immediate dangers and hazards but also to poorly designed work environments (in combination with long working hours), and poor hygiene, particularly in the bathrooms and eating areas. Workers also refer frequently to a wide range of variables related to the agency dimensions of democratic autonomy, one of the most unambiguous of which is denial of the right to organize.

Both permanent and seasonal workers in the coffee industry contend with low wages, lack of access to social infrastructure and services on farms and in surrounding communities, substantial barriers to freedom of association, and in some cases systematic subjection to sexual harassment and other forms of maltreatment or abuse. Smallholder 
producers in the coffee industry contend with low and unstable prices and incomes, compounded by a lack of access to social infrastructure and services and, frequently, insecurity of land tenure. For both smallholder producers and workers, such problems are underpinned by a lack of control over the conditions of their material disempowerment, resulting from their lack of power within existing labor and market relations, and a lack of sufficient resources to escape or transform the terms of these relations. ${ }^{12}$

Such outcomes are affected very directly by the kinds of power within global supply chains outlined above. Of particular significance in the garment industry is the way dominant buyers use their power within global supply chains to push down wages and increase workloads, with significant and direct implications for the well-being of workers. In the coffee industry, major roasting companies in consuming countries, along with some large international trading companies operating in producing countries, have exercised their power in ways that have enabled them to capture increased shares of income generated across the supply chain, while farmer income has significantly declined.

In all of these ways, the pluralist forms of corporate power outlined above affect other actors/stakeholders in ways that threaten the equal autonomous entitlements of these populations, thus generating a normative imperative for democratic control, and so prima facie appear to satisfy the normative criterion of "publicness" we have identified.

The Absence of a Sovereign Structure of Public Power Gives Rise to a Pluralist Structure of Public Power

The existence of autonomy-limiting relations of power and interconnection of transnational scope is not in itself sufficient to establish the existence of a democratic deficit. Economic 
forms of power similar to those we have described here have always limited the autonomy of those affected by the operations of corporations and markets. These have not traditionally been thought of as public forms of power because it has been assumed that sovereign state institutions should be able to constrain and govern such forms of corporate and market power whenever their autonomy-limiting impacts on individuals are judged by state authorities to lack justification or legitimacy. The assumption that corporate power is always subordinate in this way to sovereign state power precludes viewing the exercise of corporate and market power within global supply chains as normatively "public," since the proximate autonomy-limiting affects of corporate power upon the lives of individuals are viewed as ultimately emanating from the higher state authorities that permit these corporate activities, rather than from the powers of corporations themselves.

In order to show that corporate power is public in the relevant normative sense, it is therefore also necessary to examine how the forms of corporate power we have discussed are situated within broader structures of global power. Specifically, it is necessary to demonstrate that the power giving rise directly to these outcomes is not itself subordinated to the power of a responsible public agent-such as a sovereign state-empowered to regulate these specific forms of corporate power. To this extent, the autonomyconstraining power wielded by corporations through global supply chains should be understood as comprising elements of what we characterized earlier as a pluralist structure of global public power, rather than existing as transgressive blips within a global political order constructed principally around the functioning of sovereign public political structures. 
In both the garment and coffee industries the integration of producing countries into global supply chains and the wider global political economy in which they are embedded systemically constrains the capacity of many governments to discharge their designated responsibilities to regulate the autonomy-limiting powers that corporations wield over individuals within their sovereign jurisdictions. The forces acting to undermine these sovereign structures of public power differ between industries. In the garment industry the constraints on the power of the government to shape outcomes for workers results very directly from the supply chain power of transnationally mobile investors, who place direct pressure on governments not only in relation to the overall legislative framework of the labor law but also in the context of specific labor disputes. ${ }^{13}$ In the coffee industry the sources of constraint result in part from resource constraints deriving from many producing countries' historical and structural position in the world economy, and also from the broader regulatory constraints imposed by the demands of achieving competitiveness within global markets.

As a result of these constraints on the capacity of sovereign structures of public agency to bring corporate and market power under democratic control, such forms of power themselves take on a normatively public character. These forms of corporate public power then coexist alongside the public power exercised by governments and, in some cases, by other nonstate actors. Within this pluralist structure of public power, multiple and overlapping democratic constituencies correspond with these multilevel systems of power, giving rise to overlapping constituencies of democratic stakeholders holding democratic entitlements in relation to plural agents of corporate public power. 
The Challenges of Democratizing a Pluralist Structure of Public Power

The extent to which configurations of power within coffee and garment supply chains conform to (or fall short of) these institutional criteria of publicness varies according to the extent of concentration versus structural diffusion of corporate power, as well as the extent to which corporate power interacts with the power of other social actors within complex structural configurations. In both industries such diffusion and interdependence of control over core outcomes is present at several levels, though the extent of such dynamics varies between as well as within industries. To the extent that power is relatively concentrated and traceable — as in many garment sector supply chains—-both stakeholders and agents of public power can be clearly identified, and corporate agents of public power have sufficient capability to discharge public responsibilities assigned directly to them (either directly or after an appropriate process of institutional capacity building). The more pronounced the structural diffusion of power and agency, the less likely it is that power within existing configurations will embody sufficient characteristics of stability, clarity, and recognition of roles and responsibilities to enable such power to be subjected directly to democratic control.

\section{Democratizing Public Power within a Pluralist Order}

In this section we turn our attention to the prospects for establishing effective representative institutions for the democratic control of pluralist structures of corporate and market power within global supply chains. We ground our assessment of the prospects for such democratization in a critical assessment of an important set of institutional 
innovations currently evolving in global politics, which we take to embody the emergence of increasingly pluralist forms of democratic representation. These evolving processes of progressive democratization attempt to track plural, decentered configurations of established corporate power in the global economy, and to subject them to new forms of direct representative control.

We argue that there are some firm grounds for optimism about the prospects for establishing a pluralist model of democratic representation in the global domain, since such efforts to directly democratize pluralist corporate power have already enabled significant improvements to the ways some important goals and interests of marginalized workers and producers are democratically represented within global production systems. However, we also point to existing limitations of such mechanisms, associated with the incomplete and non-constitutionalized character of emerging mechanisms of non-electoral representation at the global level, and the structural diffusion of much corporate power.

Our argument here depends on the general claim—which we have developed in greater depth elsewhere-that the democratic credentials of a given set of institutional arrangements should not be viewed as a function of their facilitation of specific institutional processes, such as elections. ${ }^{14}$ Rather, such institutions should be judged to possess democratic legitimacy to the extent that they perform the democratic functions of public authorization and accountability, ${ }^{15}$ and in doing so deliver effective democratic control of public power to those stakeholders affected by its exercise. The key idea here is that democratic representation represents a particular institutional means of regulating the power relationships between rulers and ruled, in such a way as to ensure that the power exercised by public political agents remains subordinate, in some significant respects, to 
the power wielded collectively by the publics subject to this power. In short, the key purpose of democratic representation is ensuring a reasonable degree of public control over public decision-making; while elections can often deliver a useful mechanism for achieving this outcome, they are not essential to a process of democratic representation if alternative mechanisms can be found to perform an equivalent political function. ${ }^{16}$

We use this functional approach as a basis for evaluating emerging attempts to democratize pluralist corporate power via connecting plural agents of public power to their multiple overlapping stakeholder constituencies. To facilitate this evaluation, it is helpful to first identify the functional elements of processes of democratic representation, to provide a basis for analyzing potential alternatives to electoral processes with respect to each of these constituent functions.

We have explained elsewhere how these constituent elements can be specified in generalized functional terms by abstracting from the functions performed by specifically electoral mechanisms of democratic representation in the presence of a constitutionalized structure of public power. ${ }^{17}$ When we abstract from the functions of electoral representation in this way, we can recognize that democratic representation is constituted by three distinct functional elements: (1) transparency in the exercise of public power, (2) collective preference formation and signaling among affected publics, and (3) public enforcement. Achieving transparency in the exercise of public power requires transparency at two levels: in the identification of public agency, and with respect to the actions and outcomes resulting from the exercise of such agency. Collective preference formation and signaling require both some capacity for collective choice among stakeholders and a means of communicating these preferences to decision-makers. Public enforcement requires an 
effective sanctioning or enforcement mechanism to compel compliance with these preferences (or, in the final instance, some means of disempowering public decisionmakers from continuing to exercise public power).

We develop our analysis of emerging practices of democratic representation through an examination of the embryonic mechanisms contributing to each of these constitutive functions, documenting the nonstate institutional mechanisms through which these functions have been performed, as well as the transnational scope over which these institutional systems have been constituted. With reference to each political function, we evaluate the extent to which democratic representation is being effectively promoted via these nonstate mechanisms, and examine some of the functional limitations from which these continue to suffer.

\section{Public Transparency}

In order for systems of democratic representation to be created that are able to effectively track pluralist structures of public power, it is necessary for publics first to have clear knowledge of what powers are wielded by whom. Such transparency in role delineation ensures that these publics have some basis on which to allocate responsibility for public decisions, and thereby to evaluate rigorously the performance of those wielding public decision-making power. Public evaluation of public power also requires transparent disclosure of both the outcomes of decision-making processes (the substance of the decisions that have been taken), and the means employed to enact them. ${ }^{18}$

In the early 1990s, when such corporate campaigns began to emerge, public awareness of the direct power wielded by retailers and other powerful supply chain buyers 
over workers in the global South was limited, and demands by activists that such companies accept responsibility for conditions in the factories and farms from which they sourced were in most cases strongly rejected. ${ }^{19}$ In response to such prevailing assertions, the central claim that unaccountable corporate power was leading directly to violations of shared norms was articulated explicitly and forcefully by activists, who relentlessly pressed the message that "the current international economic order of trade liberalization and economic globalization ... places MNCs in positions of extraordinary power and equally extraordinary lack of accountability." ${ }^{20}$ Such campaigns generally targeted major retailers and brands in garment-sector supply chains and major roasting companies in the coffee industry.

These companies initially resisted this characterization of their role, seeking instead to point to long chains of subcontracting or arms-length market-based sourcing as evidence that violations of human rights in individual factories and farms were beyond their control. In the face of this resistance, activists worked through the construction of transnational networks to lay bare explicitly and publicly the ways in which corporations in the North exert autonomy-limiting power over workers and small producers in the South via their control of buyer-driven supply chains. Through high-profile media campaigns and/or widespread grassroots networks targeting retail outlets of familiar brands—strategies commonly referred to as "naming and shaming"-activists significantly increased public awareness of the direct power of such companies over the lives of workers and producers in faraway countries. ${ }^{21}$

In response to these efforts companies have developed a range of corporate codes of conduct whereby their public responsibility to correspond with their transnational 
exercise of autonomy-limiting forms of power is publicly acknowledged and formally codified. In both sectors, almost all leading brands, retailers, and roasting companies in most industrialized countries have put in place supply chain governance systems that codify their responsibility for protecting basic social and labor standards in the farms and factories from which their products are sourced. Some companies have further formalized these obligations by participating in a range of sectoral and broader multi-stakeholder systems of supply chain governance, such as the Common Code for the Coffee Community in the coffee sector, and the Fair Labor Association, Workers Rights Consortium, or Ethical Trading Initiative in the garment sector. To the extent that such campaigns and codes have enabled individual workers and producers to identify the multiple agents and forms of corporate public power being exercised over them, such mechanisms have played an important role in creating a pluralist system of democratic representation.

\section{Collective Preference Formation and Signaling}

Having established a means of transparently identifying power holders, establishing a system of democratic representation appropriate for democratizing a pluralist structure of public power also requires an institutional means through which democratic stakeholders can formulate collective preferences regarding how this power should be wielded, and then signal such preferences to public decision-makers.

The first step involves the creation of what are generally characterized as mechanisms of public choice (or social choice). This step is particularly important given that individual workers and producers frequently differ in their views regarding relevant decisions, such as optimal trade-offs between the maintenance of employment security 
versus the desire for higher wages and better working conditions, thereby generating conflicts within a single category of stakeholder. ${ }^{22}$ Further, in many agricultural sectors, such as coffee, production takes place on both large plantations and on smallholder farms, which can lead to a divergence of interests and preferences.

To the extent that we can reasonably understand those workers and small producers who have been identified as democratic stakeholders of corporate power as being equally affected by the exercise of such power, conflicting preferences between such stakeholders can be legitimately resolved via familiar aggregative institutional mechanisms, such as the election of worker representatives, together with appropriate processes of deliberation. Collective choice mechanisms have operated to some extent on this basis via the institutional vehicles of existing worker organizations, though the weakness and fragmentation of worker organizing in the agriculture sector has undermined the effectiveness and representative capabilities of such mechanisms.

In addition to horizontal mechanisms through which the collective preferences of relevant stakeholders can be negotiated and defined, mechanisms are required through which these preferences can be signaled to relevant power holders. The most direct kind of signaling mechanism would be one that directly links stakeholders to power wielders; and indeed it is frequently claimed that codes of conduct and factory- or farm-based monitoring and remediation systems provide some basis on which such direct forms of communication from stakeholders to decision-makers can occur. However, for the majority of workers these systems prove insufficiently transparent or participatory to enable effective stakeholder communication of this kind. ${ }^{23}$ This failing is compounded by the tendency of private sector auditors who monitor code compliance in factories and farms to devote little 
time to speaking with workers directly and, when they do, to conduct such interviews where workers are afraid to speak openly and honestly.

Given the absence of direct communication mechanisms, signaling of worker preferences, where it occurs, has tended to take place via Northern intermediaries. In the garment industry, international solidarity campaigns, in which international "solidarity" networks comprised of such nonstate actors as labor unions and NGOs are formed to support the demands of local unions in specific factories, have played a significant role in enabling networks of activists to communicate complaints from the factory level to the diverse sites of decision-making within global supply chains. In the coffee industry, networks of relationships between transnational NGOs, such as Oxfam, and both local and transnational organizations of small producers have at times enabled similar intermediary functions to be performed. In such cases, delegitimizing signals were able to be sent directly to each relevant site of corporate power within the supply chain, communicating the preferences of workers for particular changes that they believed to be more consistent with the protection and promotion of those core dimensions of their autonomy affected by the terms of their participation in garment and coffee production. ${ }^{24}$

\section{Enforcement of Collective Preferences}

Such signaling mechanisms are of little use unless sanctions can be imposed on power holders in ways that can effectively enforce the responsiveness of decision-makers to these collectively determined and communicated preferences. Therefore, in addition to mechanisms for public signaling of stakeholder preferences, the effective operation of a pluralist system of democratic representation also requires the existence of centralized or 
decentralized enforcement mechanisms, the application of which is contingent on the preferences signaled by the relevant public stakeholders.

The anti-sweatshop campaigns in both the coffee and garment industries have contributed in some limited and yet significant ways to the development of enforcement mechanisms via their ability to deploy the communicative and coordinating capabilities of their transnational networks to exert punitive forms of pressure on relevant corporate decisionmakers throughout global supply chains. To some extent, increased consumer awareness and concern regarding working conditions in offshore factories and farms has enabled activists to strategically mobilize and deploy consumer action as an independent coercive weapon. ${ }^{25}$ Such sanctioning mechanisms have operated both through direct consumer boycotts and through deeper processes of socialization manifested as broader reputational damage to company brands. ${ }^{26}$ Many firms are highly vulnerable to such pressure because of the value invested in the construction of their brands, making such strategies very successful—at least in some cases. Thus, by gradually constructing institutional mechanisms that contribute to each of these constitutive functions of transparency, formulation and communication of public preferences, and public enforcement, these nonstate accountability systems have made important contributions to strengthening systems of democratic representation within the supply chains of the global garment and coffee industries. ${ }^{27}$

Functional Weaknesses within Existing Nonstate Institutions of Pluralist Democratic Accountability 
Existing systems of democratic accountability as documented above are incomplete in several important ways, each of which gives rise to distinct functional shortcomings. First, the construction of these transnational democratic responsibilities and accountability systems has largely occurred via nonstate mechanisms (primarily networks and markets), which suffer from significant functional weaknesses in relation to coordination and enforcement functions.

Nonstate mechanisms have proved particularly weak as means of subordinating structurally diffuse forms of social power to democratic control. Dimensions of worker and producer autonomy relating to such issues as provision of employment opportunities, basic social infrastructure, and "living wages” depend importantly on structural forms of power that encompass both complex systems of corporate and market power and the wider social systems in which they are embedded. Such problems are typically the product of complex social interactions among multiple actors, across different organizational spheres of society, and through lengthy periods of time. In tackling such problems, a centralized and durable administrative apparatus able to strategically coordinate interventions across a range of actors and locations and through time, underpinned by powers of coercive taxation required to support such programmatic and redistributive functions, take on a special significance.

For a range of reasons that we have elaborated elsewhere, nonstate institutional mechanisms tend to lack the particular set of functional capabilities required to tackle such problems. ${ }^{28}$ Precisely because pluralist systems of democratic representation tend to be constituted so as to track forms of public power exercised via specific actors and organizational infrastructures, the scope of their operation is too narrow to enable them 
effectively to discharge obligations of public governance in relation to structural problems of this kind.

Second, the lack of stability and clarity of distributions of normatively public power within a structurally diffuse pluralist order significantly weakens the core function of transparency in role delineation, thus undermining the ability of democratic stakeholders to subject such power directly to democratic control. This has been a particular problem in the coffee sector, in which the diffusion of power within market-dominated supply chain relations has limited the extent to which identifiable corporate decision-makers directly control many normatively relevant outcomes. Because the operation of pluralist democratic structures depends on their capacity to identify the relationships linking specific democratic stakeholders to specific agents of public power, such an absence of direct and traceable links between specific actions of corporate decision-makers and specific forms of harm suffered by democratic stakeholders has tended to undermine attempts to construct pluralist systems of corporate accountability in this industry.

Some initial campaigns in the coffee industry attempted to frame their demands according to logics of "negative" corporate responsibilities—-that is, the responsibility not to harm workers and producers within their supply chains. Companies were accused of buying coffee from sweatshops in the field, and activists demanded that companies adopt rights-based approaches to enforcing labor codes on plantations. ${ }^{29}$ However, such claims tended not to resonate strongly with the moral intuitions of Northern consumers who were able to recognize — at least implicitly—the normative and institutional complexities introduced by the much more indirect nature of the institutions linking corporate buyers in the coffee industry to workers and producers in specific locations. ${ }^{30}$ In particular, attempts 
to use sanctioning mechanisms based largely on general threats of reputational damage have proved very weak, since general demands that roasters “do something” about problems in which they are partially implicated but not solely responsible have proved very difficult to define or enforce.

Third, the absence of an overarching constitutional structure through which distinct systems of decision-making and interaction can be articulated in relation to each other undermines the capacity of workers to control trade-offs between different goals. This creates particular barriers to the functions of collective preference formation and stakeholder signaling within a pluralist system of democratic representation.

Taken together, these functional weaknesses have undermined the extent to which emerging democratic practices have been able to effectively promote each of the functional dimensions of democratic representation identified above: transparency, collective preference formation and signaling, and enforcement. Such weaknesses have therefore limited the contribution of these emerging systems to the strengthening of democratic control and equality.

\section{Summing Up}

Our central purpose in this paper was first to highlight some of the unique challenges of democratic representation posed by a pluralist global political order-in which public power lacks a unified constitutional structure-and then to explore some of the achievements and limitations of those embryonic mechanisms of pluralist stakeholder representation that we see to be emerging. 
We suggested that there are some firm grounds for optimism about the prospects for establishing a pluralist model of democratic representation in the global domain in view of the demonstrated contribution of established pluralist mechanisms to the democratization of certain forms of corporate power. However, we also highlighted the often serious challenges confronting an agenda of pluralist global democracy in its efforts to democratize those forms of corporate power that are structurally diffused, and to rely in doing so on nonstate institutional mechanisms.

There are a number of ways in which such conceptual and institutional challenges might be confronted-in ways that vary significantly between these distinct configurations of corporate power. Functional weaknesses relating to the weak enforcement powers at the disposal of nonstate mechanisms of democratic control could be rectified to some extent via forms of institutional reform that would, in effect, constitutionalize the pluralist order. By inserting certain public norms into private mechanisms of law, ${ }^{31}$ such changes would aim to oblige private actors to accept responsibility for promoting a wider range of public goals and responding to a broader range of public stakeholders. ${ }^{32}$ Public enforcement mechanisms could also be substantially strengthened via appropriate modification of legal mechanisms that would enable affected workers to hold retail clients directly accountable in law for damages suffered in the conduct of their corporate sourcing policies. ${ }^{33}$ In this context, changes to a range of legal instruments may be appropriate; company law, labor law, tort law, contract law, and laws regarding unfair or restrictive business practices are all obvious areas in which change would probably be required.

There are also some reasons for optimism regarding the prospects for democratizing structural power within a pluralist model. The prospects are particularly 
positive in relation to forms of power identified above that are still traceable, despite some degree of structural diffusion. In the absence of a centralized, coordinating administrative apparatus constituted over appropriate transnational scope, activists, companies, and others can at least partially address such challenges by attempting to develop better conceptual and institutional mechanisms to differentiate and transparently specify partial and shared responsibilities. This would provide some means of disaggregating responsibilities among relevant decision-makers, and, where necessary, it would provide the means of coordinating those decision-making processes that interdependently affect relevant dimensions of workers' and producers’ well-being.

In some cases, existing nonstate mechanisms of democratic representation have attempted to develop means of instituting shared and partial public responsibilities of both these kinds. Some initiatives in the coffee industry have acknowledged obligations to wider "coffee growing communities," while other initiatives in both sectors have made some attempts to coordinate their governance activities with other nonstate actors and/or with government agencies. ${ }^{34}$ While such moves have to date tended to be both weak and discretionary, they provide useful illustrations of the directions future institution-building efforts could take in order to strengthen pluralist systems of democratic representation.

Despite the seriousness of the challenges outlined in this paper, such potential for progressive democratic institution building within a pluralist global order leads us to emphasize the need for intensified efforts to strengthen the pluralist democratic agenda on its own terms, rather than to abandon such an agenda on the grounds that its institutional prescriptions appear overly complex, cumbersome, or unfamiliar. In fact, we have argued that the rather unappealing "messiness" of a pluralist democratic order simply reflects the 
complex and decentralized character of the pluralist global order that we find ourselvesby necessity—confronting.

Our understanding of not only how such distinctive challenges might be effectively confronted within a democratic project but even the details of what such challenges entail remains significantly underdeveloped. In the face of such challenges, Henry Shue has lamented the tendency for normative theorists to be "flatfooted where nimbleness was required. ${ }^{35}$ We suggest that increased nimbleness is also required from those scholars and practitioners grappling with the complex institutional configurations of a pluralist global order. If the widely expressed concern for the ongoing marginalization of some of the most vulnerable participants in a global economy as a result of a persistent global democratic deficit is to be effectively tackled via an agenda of global democratic institution building, such challenges must be seriously and urgently confronted.

\footnotetext{
${ }^{1}$ Terry Macdonald, Global Stakeholder Democracy: Power and Representation Beyond Liberal States (Oxford: Oxford University Press, 2008); Terry Macdonald and Kate Macdonald, "Non-Electoral Accountability in Global Politics: Strengthening Democratic Control within the Global Garment Industry," European Journal of International Law 17, no. 1 (2006); Philip Cerny, "Plurality, Pluralism, and Power: Elements of Pluralist Analysis in an Age of Globalization," in Rainer Eisfeld, ed., Pluralism: Developments in the Theory and Practice of Democracy (Opladen and Farmington Hills: Barbara Budrich Publishers, on behalf of the International Political Science Association, Research
} 
Committee No. 16 [Socio-Political Pluralism], 2006); and Philip Cerny, "Globalization and the Erosion of Democracy," European Journal of Political Research 35, no. 5 (1999).

${ }^{2}$ Thomas Nagel, "The Problem of Global Justice," Philosophy \& Public Affairs 33 (2005). ${ }^{3}$ Ibid.

${ }^{4}$ These cases are discussed in more detail in Kate Macdonald, "Public Accountability within Transnational Supply Chains: A Global Agenda for Empowering Southern Workers?" in Alnoor Ebrahim and Edward Weisband, eds., Global Accountabilities: Participation, Pluralism and Public Ethics (Cambridge: Cambridge University Press, 2007); and Kate Macdonald, "Globalising Justice within Coffee Supply Chains? Fair Trade, Starbucks and the Transformation of Supply Chain Governance," Third World Quarterly 28, no. 4 (2007) (Special Issue: "Beyond Corporate Social Responsibility? Business, Poverty and Social Justice").

${ }^{5}$ We have tackled related problems associated with the democratization of other categories of global actors elsewhere-notably in an analysis of strategies for democratizing the power of NGOs. See Macdonald, Global Stakeholder Democracy.

${ }^{6}$ David Held, Democracy and the Global Order: From the Modern State to Cosmopolitan Governance (Cambridge: Polity Press, 1995); and Macdonald, Global Stakeholder Democracy.

${ }^{7}$ For further discussion, see Macdonald, Global Stakeholder Democracy, pp. 37-39. A closely related set of issues is discussed by David Held in his "Democratic Accountability and Political Effectiveness from a Cosmopolitan Perspective," Government and Opposition 39, no. 2 (2004). 
${ }^{8}$ See, e.g., Susan Strange, "The Declining Authority of States," in David Held \& Anthony McGrew, eds., The Global Transformations Reader: An Introduction to the Globalization Debate (Cambridge: Polity Press, 2000); Held, Democracy and the Global Order; A. Claire Cutler, Virginia Haufler, and Tony Porter, eds., Private Authority and International Affairs, Suny Series in Global Politics (Albany: State University of New York Press, 1999); A. Claire Cutler, Private Power and Global Authority: Transnational Merchant Law in the Global Political Economy (Cambridge: Cambridge University Press, 2003); and Rodney Bruce Hall and Thomas J. Biersteker, The Emergence of Private Authority in Global Governance (Cambridge: Cambridge University Press, 2002).

${ }^{9}$ A plausible case could be made for identifying a wider community of stakeholders for state governments than the territorial population subject directly to its laws, but it is beyond the scope of the present discussion to defend any specified account of the legitimate democratic stakeholders of states.

${ }^{10}$ Macdonald, Global Stakeholder Democracy.

${ }^{11}$ Gary Gereffi, "A Commodity Chains Framework for Analyzing Global Industries" (1999); available at http://eco.ieu.edu.tr/wp-content/Gereffi_CommodityChains99.pdf ; and Gary Gereffi, John Humphrey, and Timothy Sturgeon, "The Governance of Global Value Chains," Review of International Political Economy 12, no. 1 (2005).

${ }^{12}$ Macdonald, "Globalising Justice within Coffee Supply Chains?"

${ }^{13}$ K. Macdonald, "Public Accountability within Transnational Supply Chains."

${ }^{14}$ Macdonald and Macdonald, "Non-Electoral Accountability in Global Politics"; and Macdonald, Global Stakeholder Democracy. 
${ }^{15}$ It is common for the concept of authorization to be sharply separated from that of accountability, on the basis of an assumption that the former involves forms of control exercised prior to the execution of a particular decision, while the latter involves forms of control exercised subsequent to the decision. However, if we conceptualize the distribution and exercise of power as a dynamic ongoing process, the distinction between prospective and retrospective forms of control is unnecessary. In the present analysis, we therefore conceptualize processes of democratic representation as relating to ongoing processes and relationships of control, embracing dimensions of both authorization and accountability within a single set of institutional mechanisms.

${ }^{16}$ We recognize that this claim marks a radical departure from the long historical association between democracy and universal suffrage and electoral accountability, but we cannot offer a full theoretical defense of this claim within the constraints of this paper. A more developed defense is provided in Macdonald, Global Stakeholder Democracy, chap. 7.

${ }^{17}$ Macdonald and Macdonald, "Non-Electoral Accountability in Global Politics." ${ }^{18}$ Such disclosure must also be at accessible cost, in terms of the time, money, education and expertise, technology, mobility, and so forth required to access information about public decision-making. Additionally, reason giving can be regarded as an element of such transparency, helping to ensure that the decision-making process (as distinct from its final outcomes) is open to scrutiny by relevant stakeholders.

${ }^{19}$ Debora Spar and Jennifer Burns, "Hitting the Wall: Nike and International Labor Practices," Case Study, Harvard Business School, 2000. 
${ }^{20}$ IRENE, “Controlling Corporate Wrongs: The Liability of Multinational Corporations. Legal Possibilities, Initiatives and Strategies for Civil Society,” Law, Social Justice and Global Development 1 (2000); available at http://elj.warwick.ac.uk/global/issue/20001/irene.html.Even more specifically, it was claimed that "sweatshops are the result of corporate abuse, greed, excessive power and the lack of accountability.” National Labor Committee, No More Sweatshops: Campaign for the Abolition of Sweatshops and Child Labor; www.abolishsweatshops.org, accessed November 2004.

${ }^{21}$ Macdonald, "Public Accountability within Transnational Supply Chains"; and Macdonald, "Globalising Justice within Coffee Supply Chains?"

${ }^{22}$ For instance, in the case of Nicaraguan factory disputes, there have been very pronounced conflicts between the two opposing union confederations and between the unions and the influential women’s organization Maria Elena Cuadra. See Macdonald, "Public Accountability within Transnational Supply Chains."

${ }^{23}$ Stephanie Barrientos and Sally Smith, "Do Workers Benefit from Ethical Trade? Assessing Codes of Labour Practice in Global Production Systems," Third World Quarterly 28, no. 4 (2007) (Special Issue: "Beyond Corporate Social Responsibility? Business, Poverty and Social Justice"); Rhys Jenkins, "Corporate Codes of Conduct: SelfRegulation in a Global Economy," UNRISD Technology, Business and Society Programme Paper 2 (2001); and Macdonald, "Public Accountability within Transnational Supply Chains."

${ }^{24}$ Macdonald, "Public Accountability within Transnational Supply Chains"; and Macdonald, "Globalising Justice within Coffee Supply Chains?"

${ }^{25}$ Jenkins, "Corporate Codes of Conduct." 
${ }^{26}$ Virginia Haufler, A Public Role for the Private Sector: Industry Self-Regulation in a Global Economy (Washington, D.C.: Carnegie Endowment for International Peace, 2001); Jenkins, "Corporate Codes of Conduct"; and John Gerard Ruggie, "Global_Governance.Net: The Global Compact as Learning Network," Global Governance 7 (2001).

${ }^{27}$ Our claim that nonstate actors and institutional mechanisms can contribute importantly to performing regulatory functions traditionally undertaken by the state should not be interpreted as suggesting that such nonstate governance systems can wholly substitute for state institutions in the performance of such functions. An active debate continues regarding how best to reconfigure the relationship between state and nonstate governance mechanisms within a pluralist global order. We make some further brief comments on this changing relationship below. For additional analysis of this issue, see, e.g., David Vogel, The Market for Virtue: The Potential and Limits of Corporate Social Responsibility (Washington, D.C.: Brookings Institution Press, 2005); Ronnie Lipschutz with James K. Rowe, Globalization, Governmentality and Global Politics: Regulation for the Rest of Us (Routledge, 2005); Haufler, A Public Role for the Private Sector; and Kate Macdonald and Shelley Marshall, eds., Fair Trade, Corporate Accountability and Beyond: Experiments in Globalizing Justice (London: Ashgate, 2010 [forthcoming]).

${ }^{28}$ Terry Macdonald, "What's So Special About States? Liberal Legitimacy in a Globalising World," Political Studies 56, no. 3 (2008).

${ }^{29}$ Such approaches were common in many of the original campaigns against Starbucks in the mid and late 1990s; major campaigning organizations, such as Global Exchange, Organic Consumers, and US/GLEP (later US/LEAP), all adopted broadly this position. 
US/Guatemala Labor Education Campaign, "Justice for Coffee Workers Campaign," US/Guatemala Labor Education Campaign Update (1996).

${ }^{30}$ To a certain extent, such structural dynamics have also undermined harm-based, restrictive accounts of responsibility in the garment industry, particularly in relation to the question of "living wages."

31 This central point has much in common with arguments elsewhere that advocate the “constitutionalization” (Julia Black, "Constitutionalising Self-Regulation," Modern Law Review 59, no. 1 [1996]) or “juridification” (Doreen McBarnet, Aurora Voiculescu, and Tom Campbell, eds., The New Corporate Accountability: Corporate Social Responsibility and the Law [Cambridge: Cambridge University Press, 2007]) of nonstate governance initiatives.

32 Jem Bendell, "Barricades and Boardrooms: A Contemporary History of the Corporate Accountability Movement," UNSRID Technology, Business and Society Programme Paper 13 (2004); McBarnet, Voiculescu, and Campbell, eds., The New Corporate Accountability; Robert Horwitz, "Judicial Review of Regulatory Decisions: The Changing Criteria," Political Science Quarterly 109, no. 1 (1994); Karen Orren, "Standing to Sue: Interest Group Conflict in the Federal Courts,"American Political Science Review 70, no. 3 (1976)

${ }^{33}$ Such legal reforms would need to be adopted by countries in which companies incorporated, or, depending on the legal mechanism, in which they conducted retail operations.

${ }^{34}$ See Macdonald, "Public Accountability within Transnational Supply Chains"; and Macdonald, "Globalising Justice within Coffee Supply Chains?" 
${ }^{35}$ Henry Shue, "Standards of Accountability: Avoiding Simplistic Domestic Analogies" (paper presented at the Normative and Empirical Evaluation of Global Governance Conference, Princeton University, February 17-18, 2006). 